\title{
A ESCRITA CRÍtICA DE RoBERT SCHUMANN: POLIFONIA, ELISÃO E SUBJETIVIDADE
}

Resumo

Este trabalho é parte de uma pesquisa de maior abrangência, que visa à revitalização histórica de um documento e tem por núcleo a tradução ao português do Brasil dos Escritos sobre a música e os músicos, do compositor alemão Robert Schumann (1810-1856), acrescida das notas da edição crítica de Martin Kreisig (1914). Em perfeita sintonia com os ideais de seu tempo - a fluida transição entre o classicismo e o romantismo alemães -, Schumann registra em seus escritos suas impressões e comentários sobre o cenário musical da Alemanha na primeira metade do século XIX. Como nas peças musicais do compositor, as resenhas críticas revelam um conjunto de vozes que disputam a primazia no texto, bem como a impaciência de um autor, expressa nas entrelinhas, que tem em mira um público composto por um pequeno grupo de correligionários, pelos adeptos dos velhos tempos e por aqueles que cultivam o virtuosismo e a música de entretenimento.

\section{Abstract}

This paper is part of a broader research project, which aims at the historical revitalization of a $19^{\text {th }}$ Century document: the translation into Brazilian Portuguese, with the notes and comments of Martin Kreisig (1914), of the Gesammelte Schriften über Musik und Musiker (Collection of Writings on Music and Musicians) of the German composer Robert Schumann (1810-1856). Sharply attuned to the aesthetic ideals of his time - the fluid transition from Classicism to Romanticism in Germany - Schumann registers in his writings his impressions and comments about the musical scene from the first half of the $19^{\text {th }}$ Century in Germany. As in the composer's musical pieces, the critical texts reveal an assemble of voices, which contend for primacy in text, as well as the impatience of an author, expressed between lines, that had in mind a public composed by a small group of coreligionists, by the adepts of the old times and by those who cultivated virtuosity and music for entertainment.

\section{JoÃo AzeNHA JuNIOR}

Universidade de São Paulo

\author{
Keywords \\ Robert \\ Schumann; \\ musical \\ criticism; \\ Collection of \\ Writings on \\ Music and \\ Musicians; \\ polyphony; \\ presupposition.
}


ntre 1852 e 1854, aproximadamente, poucos anos antes de sua morte, Robert Schumann retomou seus escritos críticos, inicialmente publicados entre 1834 e 1844 na revista Neue Zeitschrift für Musik (daqui para frente NZfM), de Leipzig, que ele próprio fundou e de que foi seu editor chefe. Conforme relatou em sua correspondência, a ideia de reunir as resenhas num livro nasceu do esforço em legar à posteridade uma compilação ordenada de sua obra crítica e foi fruto do desejo de “... reunir, num único livro, essas páginas dispersas, em memória daqueles anos [como redator] e de mim mesmo". ${ }^{1}$

Desde sua publicação em 1854, os dois volumes de textos, ${ }^{2}$ num total de 1.210 páginas, ${ }^{3}$ têm sido objeto de estudo de musicólogos, historiadores e estudiosos da cultura, principalmente como um importante retrato do cenário musical e estético da primeira metade do século XIX na Alemanha. Para além de seu valor como documento indispensável à historiografia musical do século XIX, porém, os escritos críticos de Schumann revelam um emaranhado de relações com a literatura alemã e estrangeira produzida por autores anteriores e contemporâneos ao compositor, o que torna seu conhecimento de importância também para a historiografia literária.

O trabalho de tradução desses volumes, ${ }^{4}$ realizado a partir do reprint dos Escritos sobre a música e os músicos (daqui para frente Escritos) e da edição crítica de

${ }^{1}$ In: Robert Schumanns Briefe. Neue Folge, ed. por F. Gustav Jansen. Leipzig, 1904, p. 474 s. Salvo indicação em contrário, as traduções de todas as citações em língua estrangeira são minhas.

${ }^{2}$ Tratava-se, inicialmente, de quatro volumes, posteriormente reagrupados pelos editores em dois volumes maiores: o primeiro compreende os Tomos 1 (resenhas de 1834 até parte de 1836) e 2 (resenhas de parte de 1836 até parte de 1838) e o segundo compreende os Tomos 3 (resenhas de parte de 1838 até 1840) e 4 (resenhas de 1841 até 1843 "e mais tarde").

${ }^{3}$ Este é o total de páginas do reprint (1985) da edição original, publicada em 1854.

${ }^{4}$ Este trabalho vem sendo realizado com o auxílio do CNPq (Proc. no 305302/2009-4). 
Martin Kreisig, publicada em 1914, é acompanhado de cinco ensaios ${ }^{5}$ e tem como objetivo principal a revitalização desse documento histórico. O eixo do trabalho é a tradução crítica, comentada e anotada, sustentada por preceitos teóricos e metodológicos dos Estudos da Tradução. ${ }^{6}$ Assim concebido, este trabalho tem na tradução o primeiro e mais importante ponto de aproximação com o compositor: também para Schumann, a tradução acompanha-o desde a infância ${ }^{7}$ e se transforma, paulatinamente, na metáfora mesma de sua criação poética: o esmaecimento dos contornos que separam música e literatura aponta para a existência de uma base comum, a partir da qual as ideias se traduzem - pela intervenção do gênio romântico - ora por palavras e sentenças, ora por notas e sequências harmônicas. É desse alicerce que emerge o comprometimento temático e formal da obra musical do compositor com a literatura alemã e com o cânone literário de sua época, tão bem consolidado nos Escritos. É sob esse prisma que Schumann traduz em música sua vivência na literatura.

Para o recorte da pesquisa apresentado neste artigo, as considerações que se seguem têm por ponto de partida a tradução completa do Livro I, acrescida das notas de 1 a 237 que, na edição crítica de Martin Kreisig, ${ }^{8}$ correspondem aos comentários do crítico referentes a esse mesmo livro. As notas de Kreisig (N.K.), que figuram ao lado das notas de Schumann (N.S.), expandem, através de acréscimos e explicações, trechos obscuros da escrita elíptica do compositor. Acompanhando uma forma de notação do próprio Kreisig, empreguei na tradução os sinais "|...." e " $\varnothing$ " para indicar, respectivamente, a substituição de segmentos textuais e a supressão de passagens, sempre levando em conta a edição crítica. Excetuadas unicamente as modificações ortográficas introduzidas por Kreisig em 1914, mantiveram-se, na tradução, as opções do compositor para títulos e subtítulos de obras. Por se tratar de traduções inéditas, as páginas que se seguem aos exemplos apresentados referem-se à passagem correspondente, em alemão, da referida edição crítica dos Escritos.

${ }^{5}$ Cf. João Azenha Jr., Robert Schumann, tradutor. TradTerm, São Paulo, v. 8, p. 51-56, 2002; Idem, Tradução é movimento: uma leitura do romantismo alemão. Revista da ANPOLL, São Paulo, n. 14, p. 31-56, 2004a; Idem, The translator as creative genius: Robert Schumann, in G. Hansen et al. (ed.) Claims, Changes and Challenges in Translation Studies. Selected Contributions from the EST-Congress, Copenhagen 2001. Amsterdam, Philadelphia, John Benjamin, 2004b, p. 209-218; Idem, Robert Schumann e as Letras: a música como tradução da literatura, Revista Itinerários, Araraquara, n. 26, p. 205-216, 2005; Idem, Goethe e a tradução: a construção da identidade na dinâmica da diferença, Revista Literatura e Sociedade, São Paulo, n. 9, p. 44-59, 2006.

${ }^{6}$ Sobre o arcabouço teórico e metodológico que sustenta o trabalho de pesquisa e tradução, cf. Azenha 2009.

7 Sobre a atividade de Robert Schumann como tradutor, cf. Azenha 2004b.

${ }^{8}$ Martin Kreisig (1856-1940), pedagogo alemão e fundador do Museu e da Sociedade Robert Schumann, substitui Friedrich Gustav Jansen (1831-1910) - contemporâneo de Schumann e o primeiro responsável pela compilação, organização e revisão crítica do espólio de Robert Schumann - na tarefa de reeditar os Escritos. Sobre as características da edição crítica de Kreisig e sua importância para esta pesquisa, cf. João Azenha Jr., Robert Schumann (1810-1856) e os Escritos sobre a Música e os Músicos: a música como tradução da literatura, 2009, 324 p. tese (livre-docência), Faculdade de Filosofia, Letras e Ciências Humanas, Universidade de São Paulo, São Paulo, 2009. 


\section{A escrita crítica de Schumann: polifonia}

Robert Schumann não é para ser lido, nem absorvido rapidamente. Talvez resida aqui o maior desafio para seus leitores em nosso tempo. Sua escrita elaborada Schumann sempre foi um crítico feroz de si mesmo -, crivada de aforismos, máximas e adágios tão ao modo e ao gosto do romantismo alemão, convida mais à pausa do que ao movimento:

Uma boa vontade que não seja sustentada pela força do talento é menos prejudicial à arte do que a presunção desprovida de talento. À abelha se perdoa o ferrão da bolsa de mel, mas não à vespa, que não a possui. (O Psicômetro, p. 101-105)

ou então

A coisa mais difícil que uma pessoa totalmente versada na arte do teclado possa escrever é mais fácil de se executar do que a mais fácil vinda de um leigo. (A. Bohrer, [trio] para pianoforte, violino e violoncelo. O. 47, p. 169-172)

Robert Schumann também não é um só. Homem de saúde frágil, atormentado, Schumann é, antes de tudo, plural. Seus vários heterônimos detêm, cada um a seu modo, diferentes traços de sua personalidade. Na escrita como na música, ${ }^{9}$ esses desdobramentos emprestam sua voz aos textos e às composições musicais para, através deles, defenderem e preservarem sua individualidade. E o fazem sempre no interior de um tom: se "duro" ou maior (do alemão Dur), ou "mole", menor (do alemão Moll); se brilhante e seguro, portanto, ou introspectivo e frágil. Assim são, nos Escritos, as intervenções de Florestan e Eusebius, os dois heterônimos mais conhecidos, antagônicos e complementares.

Eusebius é o sonhador, o poeta: sua sintaxe é complexa, em grande parte marcada pela ordem indireta, por uma escolha lexical afinada com o romantismo, repleta de figuras de linguagem. Nas Cartas de um entusiasta (p. 116-122), por exemplo, Schumann-Eusebius conversa com Chiara (Clara) e estabelece relações, no texto, com a cena cultural da Leipzig da época. Como todo o discurso é construído tendo em mira um interlocutor quase ideal, penso que Schumann, ao selecionar e rever suas resenhas, provavelmente teve pouco tempo para refletir sobre se o que excluía ou acrescia ao volume resistiria ao tempo sem perder o vínculo com aquela realidade específica. Penso, também, que Schumann não contou com a ajuda de ninguém ao fazer isso; concentrou todo o trabalho em si mesmo, como era seu costume. Só isso explica algumas supressões no aspecto técnico do trabalho, sobre as quais falarei adiante, e a manutenção de referências textuais à realidade de Leipzig e de sua vida pessoal que, como nesta carta de

\footnotetext{
${ }^{9}$ É interessante observar que os heterônimos da escrita de Schumann, tão presentes neste Livro I dos Escritos, também assinam várias de suas composições musicais, principalmente dos ciclos para piano da década de 1830. Nas Davidsbündlertänze op. 6, por exemplo, compostas entre 1834 e 1836, as peças são assinadas alternadamente por Florestan e Eusebius, às vezes pelos dois. Desse modo, mais uma vez, escrita e música se entrelaçam e, juntas, emprestam concretude e coerência a um compositor que se desdobra em muitos.
} 
Eusebius, teriam pouca chance de resistir à ação do tempo e iriam de encontro ao propósito de “... reunir, num único livro, essas páginas dispersas, em memória daqueles anos [como redator] e de mim mesmo".

Das muitas manifestações de Eusebius, esparsas principalmente pelas resenhas dos anos 1834 e 1835, época em que a presença desses dois membros da Confraria de Davi - Eusebius e Florestan - se fazia sentir de maneira mais forte, escolho e transcrevo a seguir, acompanhada de suas notas, a primeira das Cartas de um entusiasta. Penso que o texto, por si só, se não esgota as possibilidades de expressão de Eusebius, pelo menos é bastante ilustrativo para o que afirmei acima. Além do mais, e seguindo o modo escolhido por Schumann para caracterizar seus heterônimos, nada melhor do que entregar a palavra ao próprio Eusebius:

1.

Eusebius a Chiara

Entre todas as estrelas do nosso firmamento musical há sempre um rosto de anjo que desponta e que se parece muito com o rosto de uma tal Klara, inclusive por aquela expressão marota no queixo. Porque não estás aqui conosco e o que pensaste de nós, Firlenzer, ontem à noite, desde o Silêncio do Mar até ao ardente final da Sinfonia em si bemol maior? ${ }^{10}$

À parte o concerto em si, não conheço nada de mais bonito do que a hora que o antecede, em que se sussurram melodias etéreas com a ponta dos lábios, anda-se com cuidado para baixo e para cima, na ponta dos pés para não fazer barulho, executam-se aberturas inteiras nas vidraças das janelas ... E o relógio avisa: faltam quinze minutos. Então subimos, Florestan e eu, os degraus reluzentes da escadaria. "Sebb" - disse ele - "hoje eu estou ansioso por uma série de coisas: primeiramente por toda a música em si, pela qual estamos ávidos depois do árido verão; depois por F. Meritis, que parte para a batalha pela primeira vez com sua orquestra, depois pela cantora Maria e sua voz de sacerdotisa de Vesta; e, por fim, pelo público que - como você sabe - não me diz lá muita coisa e que espera toda a sorte de prodígios ...". No local indicado para a entrada do púbico, ficamos parados diante do velho castelão com aparência de comendador, que tinha muito a fazer e que por fim, de cara amarrada, permitiu que nós entrássemos, pois Florestan - como de costume - havia esquecido seu ingresso. Quem visse minha expressão ao entrar na sala que resplandecia em dourado, teria esperado de mim o seguinte discurso: "Com pés muito leves piso este terreno, pois a mim me parece ver despontarem aqui e ali os rostos daqueles a quem a bela arte concedeu a graça de enlevarem e encherem de felicidade centenas de pessoas ao mesmo tempo. Vejo ali Mozart, acompanhando com os pés o ritmo da sinfonia, e com tanta intensidade que a fivela do sapato chega a se soltar; mais ali, o velho mestre Hummel, improvisando ao piano; um pouco mais à frente, Catalani tirando o chale, pois o tapete que servia de forração havia sido esquecido; ali Weber, aqui Spohr e tantos outros. E então pensei também em ti, Chiara, Pura, Clara ${ }^{\varnothing 11}$ - olhando aqui para baixo do teu camarote com a Lorgnette, que te cai tão bem. Em meio a esses pensamentos deparei-me com o olhar furioso de Florestan, plantado no canto da porta onde sempre costumava ficar; e na ira dos seus

10 [N.K.] (Escritos, 116, acima) Chiara = Klara Wieck, embora essas cartas na realidade não tenham sido enviadas a ela. Firlenzer = habitantes de Leipzig [N.T. - A edição da Reclam traz a seguinte observação: "alcunha atribuída por Schumann a Leipzig, derivada do italiano Firenze (Florença)"]. Meritis (algumas linhas à frente!) = Mendelssohn, que regeu pela primeira vez em 4 de outubro. Maria = Henriette Grabau.

${ }^{11}$ [N.K.] (Escritos, 116, abaixo) Suprimido: "com as mãos apontando para a Sicília, para onde teu anseio te chama, os olhos sonhadores, porém voltados para nós". 
olhos podia-se ler mais ou menos o seguinte: "Poder tê-lo novamente aqui reunido, meu público, e atiçar-vos uns contra os outros ... há muito tempo venho querendo organizar concertos para surdos-mudos, a vos servir de modelo, minha gente, sobre como se comportar em concertos, principalmente nos mais bonitos ... como Tsing-Sing, ${ }^{12}$ vós deveríeis ser petrificados em pagodes se vos passasse pela cabeça recontar a outros uma que fosse das muitas coisas que vistes no país mágico da música" etc. O repentino silêncio sepulcral que se instalou entre as pessoas interrompeu meus pensamentos. F. Meritis entrou na sala. E já no primeiro instante voaram até ele centenas de corações. ${ }^{13}$

Acaso te lembras daquela noite em que partimos de Pádua descendo pela comuna de Brenta? O calor ardente da noite italiana fechou-nos os olhos, primeiro de um, depois do outro. De repente, na manhã seguinte, uma voz brada: "Ecco, ecco, Signori, Venezia!" - e o mar se estendia ante nossos olhos, vasto, calmo, a perder de vista; do ponto mais distante no horizonte, porém, ouvia-se um tilintar suave, como se as marolas conversassem umas com as outras, em sonho. Também n' O silêncio do Mar ${ }^{14}$ tudo respira e balouça e, tomados por um estado de sonolência, somos mais pensamento do que seres pensantes. O coro beethoveniano inspirado em Goethe e a palavra acentuada soam quase rudes ao lado da sonoridade tecida pelos violinos quase como uma teia. Próximo ao final, uma harmonia se desprende e temos a impressão de que os olhos sedutores de uma filha de Nereus olham para o poeta para levá-lo ao fundo do mar, mas então, pela primeira vez, uma onda ergue um pouco mais o tom de sua voz e o mar vai se tornando cada vez mais loquaz, e as velas desfraldadas se agitam ao vento, e também as divertidas bandeirolas - Vamos! - À frente, à frente, à frente ... "Qual sinfonia de F. Meritis é a minha preferida?", perguntou-me um simplório. E nesse momento as tonalidades de mi menor, si menor e ré maior ${ }^{15}$ deram-se os braços para formar um acorde de Graças e eu não pude responder outra coisa, a não ser: "Todas e cada uma delas". F. Meritis regia como se ele próprio tivesse composto a Abertura; e a orquestra o acompanhava. Foi quando uma observação de Florestan me chamou a atenção. A música estaria sendo executada da forma como ele costumava tocar quando veio do interior para estudar com Mestre Raro: "A crise mais difícil que eu tive de enfrentar (prosseguiu ele) consistiu desse estado intermediário entre arte e natureza. Da forma ardente como eu sempre concebia tudo, tive de passar a fazer tudo lento e com clareza, pois me faltava completamente a técnica: o resultado disso foi um refreamento brusco, uma rigidez tamanha, que cheguei a duvidar do meu talento; por sorte, a crise não durou muito tempo". Quanto à minha pessoa, incomodava-me tanto na Abertura quanto na Sinfonia a batuta do regente marcando o compasso ${ }^{16}$ e eu concordei com Florestan, cuja opinião era a de que, na Sinfonia, a orquestra tinha de funcionar como uma república, que não reconhece ninguém como lhe sendo superior. De qualquer forma, foi reconfortante ver F. Meritis antecipando com os olhos e em cada pequena nuança, da mais sutil à mais vigorosa, as mudanças de atmosfera das composições, nadando à frente de todos como o mais bem-aventurado; muito diferente do que costuma acontecer, quando nos deparamos com um mestre de capela que ameaça bater na partitura, na orquestra e no público com seu cetro. - Sabes muito bem quão pouco eu suporto as discussões sobre tempo e andamento e como para mim a única coisa que conta e que faz toda a diferença é a medida do movimento que cada um traz dentro de si. Assim, o adágio mais acele-

12 [N.K.] (Escritos, 117, acima) Tsing-Sing, a personagem cômica da Féerie chinesa de [Daniel François Esprit] Auber [1782-1871], O cavalo de bronze [1835].

13 [N.K.] (Escritos, 117, acima) Em 4 de setembro, Schumann anunciou a chegada de Mendelssohn na Revista com as seguintes palavras: "Felix Mendelssohn-Bartholdy chegou a Leipzig para reger os próximos concertos de inverno na sala da Gewandhaus. Não temos nada a acrescentar a este anúncio, além daquilo que poderia dizer cada um dos que o veneram do fundo do coração".

14 [N.S.] Abertura de Mendelssohn.

15 [N.K.] (Escritos, 117, abaixo) Sonho de uma noite de verão, As Hébridas e O silêncio do mar.

16 [N.S.] Antes de Mendelssohn, quando [Heinrich August] Matthäi [1781-1835] estava à frente da orquestra, as peças orquestrais eram executadas sem um regente a marcar o compasso. 
rado de um homem frio me é mais suportável do que o adágio mais lento de um fleumático. Em se tratando da orquestra, porém, entram em jogo as massas, o conjunto dos instrumentos: as mais rudes, mais adensadas, podem conferir mais expressão e importância tanto ao detalhe como ao conjunto; em se tratando de conjuntos menores, mais refinados, como a nossa de Firlenz, há que se suprir a falta de ressonância com andamentos mais acelerados. Numa palavra: o Scherzo da Sinfonia me pareceu lento demais ${ }^{17}{ }^{17}$ deu para perceber isso claramente já pela inquietação dos componentes da orquestra, que teriam de estar tranquilos. Mas que diferença pode fazer a Ti, em tua Milão, e que diferença, no fundo, faz a mim também o fato de eu a cada momento pensar no Scherzo como bem entendo? Tu me perguntas se Maria teria recebido a mesma acolhida de outrora em Firlenz. E como podes duvidar disso? - só que ela escolheu uma única ária ${ }^{18}$ que lhe trouxe mais honra como artista do que aplausos como virtuose. Um Diretor de Música da Vestfália ${ }^{19}$ também tocou bem um concerto para violino de Spohr, só que pálido e magro demais. Já na própria escolha do repertório todos quiseram ver uma mudança na direção artística; se, nos primeiros concertos de Firlenz, não faltaram borboletas italianas voando em volta de carvalhos alemães, desta vez estes últimos estiveram totalmente sozinhos, tão vigorosos quanto sombrios. Um certo partido quis ver nisso uma reação; de minha parte, considero o fato mais obra do acaso do que de uma intenção. Todos nós sabemos que é necessário proteger a Alemanha da invasão de Teus favoritos; contudo, que isso aconteça com todo o cuidado e mais através do estímulo a jovens artistas de nossa pátria do que por discursos inúteis contra um poder (que, como uma moda, vem e vai ${ }^{20}$ ). À meia-noite, Florestan chegou com Jonathan, um novo davidiano. Os dois discutiam vivamente sobre a aristocracia do espírito e a república das opiniões. Finalmente Florestan encontrou um opositor que lhe põe às mãos diamantes para ele quebrar. Sobre essa figura forte, terás mais detalhe um pouco mais tarde. ${ }^{21}$

Por hoje, basta. Não te esqueças de dar uma olhada de vez em quando no calendário, mais especificamente no dia 13 de agosto $^{22}$, em que uma Aurora une meu nome ao teu ${ }^{\varnothing}{ }^{23}$ (p. 116-119)

17 [N.K.] (Escritos, 118, acima) Sinfonia em si bemol maior, de Beethoven.

${ }^{18}$ N.K.] (Escritos, 118, ao meio) Ária de K. M. v. Weber, inserida em Lodoiska.

${ }^{19}$ [N.K.] (Escritos, 118, ao meio) Otto Gerke.

${ }^{20}$ [N.K.] (Escritos, 119, acima) Suprimido: "Que o nobre artista não lhes dê ouvidos, distancie-se dos estouros da pirotecnia e volte-se para a noite estrelada que, se mais fria, ainda assim é mais pura; mas a reflexão estafante faz o povo bocejar e a profundidade alemã, depois da superficialidade italiana, só lhe parecerá ainda mais profunda. Chega de Donizettis e Paccinis, mas preservai vossa honra a Rossini e Bellini, por razões há muito conhecidas..."

${ }^{21}$ [N.K.] (Escritos, 119, acima) Pairam muitas dúvidas sobre quem seria a personalidade por detrás deste "Jonathan". A suposição de Wasielewski, de que seria L. Schunke (já falecido em dezembro de 1834), não foi compartilhada por Jansen. É bem mais provável que Schumann se refira a Chopin, que ele conheceu pessoalmente nos primeiros dias de outubro de 1835. Sobre este encontro, ele fala na Revista, em 6 de outubro (1835, Tomo 3, p. 112): "Chopin esteve aqui, mas apenas por poucas horas, que passou em círculos mais íntimos. Ele toca exatamente como compõe: de forma absolutamente singular". O final desta "Carta de um entusiasta" (que se encontra no número de 20 de outubro) condiz bem com o caráter dos dois davidianos: Florestan, de um lado, que "se lança" sobre Chopin e logo começa a discutir com ele, e Eusebius, de outro, que fica "paralisado" à simples ideia de ter de falar com esse homem venerado. A Revista possui apenas dois artigos (de 1836) assinados por "Jonathan", mas que são do próprio Schumann. Também em outros momentos ele fez uso da assinatura de outro davidiano.

22 [N.K.] (Escritos, 119, acima) Naquela época, os dias 12, 13 e 14 de agosto eram dos nomes Klara, Aurora e Eusebius, respectivamente.

${ }^{23}$ [N.K.] (Escritos, 119, acima) Suprimido: "Chopin esteve aqui. Florestan se lançou para cima dele. Vi os dois de braços dados, mais pairando do que andando com os pés no chão. Não conversei com ele. A simples ideia me deixou paralisado". 
A carta de Eusebius a Clara - por sinal, o estilo epistolar é uma das formas prediletas de Schumann ao escrever suas resenhas - já nos apresenta um pouco de Florestan, homem de "olhar furioso", parado à soleira da porta, de onde observava as pessoas que haviam ido assistir ao concerto e, com escárnio, pensava: "Poder tê-lo novamente aqui reunido, meu público, e atiçar-vos uns contra os outros ... há muito tempo venho querendo organizar concertos para surdos-mudos, a vos servir de modelo, minha gente, sobre como se comportar em concertos, principalmente nos mais bonitos ...".

Essa outra metade do duplo de Schumann, Florestan, igualmente entusiasta, mas também iconoclasta, é uma figura objetiva: fala numa sintaxe mais simples, usa a ordem direta, despreza as figuras de linguagem, tem no discurso as marcas da oralidade. A fim de deixar Florestan falar por si mesmo, escolho um trecho da terceira Carta de um entusiasta. Nela, Florestan aparece apresentado por seu amigo Eusebius, que também assina esta terceira carta, e assim se manifesta sobre a presença de compositores italianos na cena alemã:

[...] Eu estava certo em não ver nenhuma reação intencional no programa do concerto anterior, pois já os próximos trouxeram algumas Hesperíades. Nesse sentido, minha melhor diversão foi mesmo Florestan, que se entediou a não mais poder e só por obstinação contra alguns Händelianos e outros -ianos, que falam como se tivessem composto o Sansão de pijamas, não parte para destruir as Hesperíades, mas as compara, por exemplo, com "sobremesa de fruta" ou "carne de Ticiano sem espírito"; tudo isso, é claro, num tom tão cômico, que se poderia rir às gargalhadas, se isso não fizesse seu olhar de águia voltar-se para baixo. "Na verdade" (disse ele em certa ocasião) "está completamente fora de moda ficar irritado com as coisas italianas. Afinal, para que bater com clavas em odores de flores, se eles vêm e depois se vão? Eu não saberia dizer em que mundo preferiria viver, se num mundo cheio de Beethovens rebeldes, ou se num mundo cheio de cisnes de Pesaro dançantes. ${ }^{24}$ Só duas coisas eu não consigo entender: primeiro, porque as cantoras, que, aliás, nunca sabem o que devem cantar (excetuando-se, claro, cantar tudo ou não cantar nada), porque elas não se limitam a cantar peças pequenas - um Lied de Weber, Schubert, Wiedebein - e, segundo, a reclamação dos compositores de música vocal alemã de que tão pouca coisa de sua autoria aparece nos programas de concertos. Ora, porque então eles não pensam em peças para concertos, árias e cenas para concertos e se põem a compô-las?" (p. 119-122)

É talvez com Florestan que a ironia, em Schumann, ganha sua feição mais acre. Usando a mesma carta escrita por Eusebius, Schumann coloca na voz de Florestan as palavras de uma quarta pessoa - o articulista da Revista Cäcilia -, que teria publicado, em 1825, uma tentativa de interpretação para a Sinfonia Pastoral, de Beethoven. Vejamos, então, a forma irônica com que Florestan reconta a interpretação do articulista:

Retomando, então, a sinfonia - a ideia não é minha, mas de alguém que escreveu num antigo número da Cäcilia ${ }^{25}$ (e que, talvez por uma delicadeza exagerada para com Beethoven,

${ }^{24}$ [N.K.] (Escritos, 119, abaixo) Rossini era natural de Pesaro. Daí sua alcunha "o cisne de Pesaro".

25 [N.K.] (Escritos, 121, abaixo) Foi K. Fr. Ebers quem publicou na Cäcilia (1825, p. 271) uma tentativa de interpretação da Sinfonia, a partir da qual, provavelmente, ganhou forma e se difundiu a 
de que ele bem poderia ter-se poupado, transporta tudo para o refinado salão de um conde ou coisa que o valha) ... - trata-se de bodas muito animadas; a noiva, porém, é uma criança angelical com uma rosa no cabelo; uma só. A menos que eu esteja muito enganado, na introdução os convidados chegavam todos juntos e cumprimentavam-se uns aos outros com tapas nas costas; ainda se não me engano, flautas engraçadas fazem lembrar que em todo o povoado, cheio de mastros enfeitados com fitas coloridas, reina alegria pelo casamento da noiva chamada Rosa; se não me engano, ainda, a mãe da noiva, pálida, lança à filha olhares cheios de temor, como se perguntasse: 'Já sabes que teremos de nos separar?', e de como Rosa, num gesto comovente, lança-se aos braços da mãe, enquanto com uma das mãos arrasta o jovem consigo ... E então reina o silêncio no povoado" - (nesse ponto, Florestan chegou ao Allegretto e só aqui e ali deixa transparecer algumas partes) -, "só uma borboleta passa voando, ou então uma flor de cerejeira cai ao chão ... O órgão começa a tocar; o sol está a pino; alguns raios longos e oblíquos brincam com partículas de poeira suspensas na nave central, os sinos repicam a plena carga - aos poucos, os frequentadores da igreja vão chegando e se acomodando, cadeiras vão sendo abertas e fechadas - alguns camponeses leem com toda atenção o livro de cânticos, outros olham para as galerias da igreja lá no alto - o cortejo se aproxima - na frente, meninos em coro com velas acesas e bacias com água benta, logo depois os amigos, que se viram toda hora para o casal que o padre acompanha, os pais, amigas e, bem atrás, todos os jovens do povoado. E como tudo isso se ordena depois e o padre sobe ao altar e dirige suas palavras primeiramente à noiva, depois ao mais feliz dos homens, e como explica aos dois os deveres da união e suas finalidades e diz que eles encontrariam a felicidade na harmonia e no amor e como pede depois a ela o seu 'sim', que dura uma eternidade, e ela finalmente o diz, com firmeza e pausadamente - tudo isso eu me permito deixar de lado na retratação da cena para que possais dar a ela o Finale que bem entenderdes"..... Florestan interrompeu sua fala, partiu para o final do Allegretto e ele soou como se o sacristão fechasse com toda a força a porta, de sorte que o som da batida ecoasse por toda a igreja ...

\section{Neste exemplo, é interessante observar que os heterônimos de Schumann se desdobram em outros e trazem para o interior do discurso as alcunhas de outros}

lenda das bodas. O artigo escrito por Ebers deu ensejo a estas considerações sumárias de Schumann sobre o tema, mas aquele está para estas como a prosa está para a poesia. O trabalho de Ebers termina com um apelo direto ao próprio Beethoven, o que deve ter movido o compositor a se manifestar sobre suas intenções. - Não se pode deixar de mencionar que foi Gustav Nicolai quem estabeleceu como líquido e certo o fato de que Beethoven teria pretendido representar em sua Sinfonia em lá maior um casamento de camponeses. Contudo, embora ele designe expressamente a declaração do próprio Beethoven como sendo "de base histórica" (Arabesken für Musikfreunde, Revista 1835, Tomo 1, p. 128), a confiabilidade de sua informação não pode ser considerada suficientemente comprovada. // Contudo, mais valioso do que o relato oficioso de Nicolai para a interpretação do final da Sinfonia em lá maior é um fato, que Sir George Grove descobriu e comunicou a Jansen. O tema do final apresenta uma curiosa coincidência com o epílogo do Lied irlandês Nora Creina, adaptado por Beethoven. // Sinfonia [em pentagrama] // Epílogo do Lied [em pentagrama]. // A estrofe final do texto diz o seguinte: Fort mit Weisheit, trüb und alt, / Ha! Narretei nur mag uns frommen; / Still mein Lied - ein Laut erschallt, - / Der Reigen naht - die Tänzer kommen. / Wird dort einer, der mich sieht, / Mir Lust und Narrheit taumelnd preisen, / Er nur, der mich so beriet, / Beim Himmel! Machte mich zum Weisen. / (Coro) Du, der mehr als Weise weisst, / Sing dein Lied aus voller Brust; / Dankbar lauscht der Jugend Geist / Dem Wort, das Liebe rät und Lust. [N.T. - Em tradução aproximada: Chega de sabedoria, turva e velha, / Ah! Só a insensatez nos pode ajudar; Silêncio, canto meu, - um som ressoa. / A roda começa a se formar - os dançarinos chegam. / Aquele ali, que me vê, / Exalta em mim, cambaleante, o prazer e a insensatez. / Só ele, que assim me aconselhou, / Pelos Céus! Fez de mim um sábio. / (Coro) $\mathrm{Tu}$, que mais sabes que os sábios, / Canta teu canto de peito aberto. / Agradecido escuta o espírito da juventude / À palavra que o amor aconselha e o prazer.] // Beethoven adaptou as canções irlandesas (e outras) entre 1810 e 1815; a Sinfonia ele a concluiu em maio de 1812. 
davidianos: Schumann empresta voz a Eusebius, que fala com Chiara (Clara) e se refere a Zilia (outro apelido da mesma Clara); depois passa a palavra a Florestan, que fala de Meritis (alcunha de Mendelssohn na Confraria de Davi) tocando um concerto de Mendelssohn, quer dizer, do próprio Meritis, e assim por diante. A exemplo da música, em que esses dois personagens se alternam em composições que retratam estados de alma díspares, mas complementares, também no texto schumanniano essa polifonia se faz presente e demanda sua reconstrução na tradução. Por detrás dela está Schumann, aficionado confesso por Bach, apresentando em letras temas e contratemas sustentados por vozes que dialogam; reconstruindo, na tessitura do discurso, a estrutura da fuga.

Outro heterônimo, de presença mais discreta nos Escritos, merece ser mencionado, ainda que brevemente. Trata-se de Mestre Raro que, na bibliografia sobre Schumann, é tido como uma recriação de Friedrich Wieck (1785-1873), pai e professor de Clara, por muitos anos professor de piano também de Schumann e depois - nos conturbados anos que antecederam ao casamento do compositor com Clara - um forte opositor, cujo posicionamento contrário à união dos dois acabou gerando uma disputa judicial.

A despeito disso, Mestre Raro aparece no texto de Schumann como a voz da ponderação, o apaziguador das contendas entre Eusebius e Florestan, o homem que, com o peso de sua experiência, detém a sabedoria e está acima das disputas. Em suas falas, Raro é simples, direto, objetivo. Suas ponderações têm a característica de trazerem à baila argumentos que, no calor da hora, não foram aventados pelos personagens da contenda. Por suas próprias características, é em Raro que nos deparamos com um grande número de aforismos e máximas. Nesse sentido, penso que é através dele que Schumann consegue externar sua afinidade com essa forma concisa de proferir julgamentos, tão bem quista pelos românticos.

Apresento a seguir apenas alguns dos vários momentos em que Raro interfere no curso dos acontecimentos apresentados nos Escritos. Os quatro primeiros foram extraídos do Livrinho de pensamentos e poemas de Mestre Raro, Florestan e Eusebius; o último vem dos Aforismos:

Uvas acres, vinho ruim. (p. 19)

Tríade $=$ tempos. A terça revela passado e futuro como presente. (p. 23)

As obras da juventude de compositores que se tornaram mestres são vistas com olhos totalmente diferentes do que aquelas que, mesmo sendo tão boas quanto as primeiras, só prometeram coisas e não mantiveram sua promessa. (p. 24)

A primeira concepção [de uma obra] é sempre a mais natural e a mais bela. A razão engana, o sentimento não. (p. 25)

Não intervenhais no tempo; dai aos jovens os velhos para estudarem, mas não exijais deles que levem a simplicidade e o despojamento ao ponto da afetação. Purificai-os, a fim de que façam uso inteligente dos recursos da arte recentemente expandidos. (p. 30)

Toma cuidado, Eusebius, para não menosprezares demais o diletantismo (no melhor sentido da palavra), que é inseparável da vida artística. Pois o dito "Se é artista, então é porque conhece" deve ser visto apenas como meia-verdade, enquanto não se conseguir provar que um período houve, no qual a arte floresceu sem aquela interação recíproca. (p. 112) 
Como sabemos, o homem por detrás dessas vozes é Schumann. Separá-lo de cada um de seus heterônimos é algo artificial e realizado aqui apenas para atender às exigências de uma representação mais clara. Isso porque é espantoso ver como essas vozes, que lutam acirradamente por preservarem sua identidade, continuam ecoando em todos os momentos em que o compositor, ele próprio, assina aquilo que escreve.

Esses desdobramentos do compositor, atestados em seus Escritos, trazem à tona, é natural, a referência a fatos de sua vida. Contudo, não pretendo aqui entrar em detalhes sobre dados biográficos de Schumann, sobre a enfermidade que o levou ao sanatório de Endenich, nas proximidades de Bonn, nem sobre sua tentativa de suicídio em Düsseldorf, em 1854, dois anos antes de morrer. Se esquizofrênico ou não, do ponto de vista da medicina, Schumann foi corajoso o bastante para transformar a depressão em produtividade; para viver várias vidas numa só; para deixar falarem aqueles com quem convivia em seu interior; para trocar de máscaras, vivendo intensa e plenamente cada um dos estados de alma alternantes que marcam a existência e a supremacia do sujeito no romantismo.

O baile de máscaras, as sensações fugidias, as incertezas e convicções expressas na brandura (Eusebius), nas explosões de raiva (Florestan) aplacadas no instante seguinte pela voz da razão (Raro), tudo isso está na música e nos escritos de Robert Schumann. É desse cadinho de emoções fortes que nascem a unidade e a coerência do compositor, assim como os contornos de sua escrita personalíssima. Uma decorrência lógica do compromisso profundo que ele selou com seu tempo.

Complexo na vida, complexo na escrita. Conforme veremos a seguir, a crítica que Schumann inaugura na esteira de E.T.A. Hoffmann é muito pouco objetiva. Ela é, antes de tudo, a união perfeita da erudição com uma personalidade obcecada pela perfeição, o que impôs ao compositor a hercúlea tarefa de absorver tudo à sua volta - da literatura trivial às obras de grandes mestres e à filosofia - e de viver cada instante do cotidiano com toda a intensidade, rigor e disciplina. ${ }^{26}$

A exigência para consigo mesmo desdobra-se na exigência para com seu público, tanto ouvinte, quanto leitor. Daí sua escrita repleta de pressuposições. É como se ele perguntasse a si mesmo: Como é possível alguém não conhecer isso? A consequência imediata dessa atitude são as lacunas. Lacunas que começam na dificuldade de compreensão da estrutura alemã - Schumann faz uso de parágrafos extensos, longos encadeamentos, períodos complexos, ordens inversas, sabe marcar o registro de seu discurso com uma escolha lexical primorosa, traz para o texto marcas da oralidade, regionalismos, discute (e ironiza) o emprego de galicismos, entre tantos outros recursos linguísticos - e terminam na dura constatação, para grande parte dos leitores de hoje, de que seu conhecimento sobre ele e sobre o romantismo alemão estava erigido sobre estereótipos.

A fim de organizar minimamente as considerações seguintes, pretendo caracterizar a complexidade da escrita de Schumann tomando por base: (1) o desafio,

\footnotetext{
${ }^{26}$ Em seus Diários, deparamos com extensas passagens em que o compositor - como um contador cheio de escrúpulos - apresenta seu orçamento doméstico descrito em minuciosas listas de ganhos e despesas.
} 
para o leitor, imposto por sua erudição; (2) as pressuposições, decorrentes da erudição e da impaciência, que permeiam seu discurso; e, como decorrência, (3) a não objetividade. Reunidas, essas três características definem os contornos de uma crítica marcada pela subjetividade e pela generalidade, na contramão, por assim dizer, do que se esperaria hoje da atividade de um crítico.

\section{A escrita crítica de Schumann: elisão e subjetividade}

Desde muito cedo, Robert Schumann foi um leitor voraz: não só se esforçava para ler (e incorporar essas leituras às suas composições e escritos) obras exponenciais da literatura contemporânea à sua época - alemã e estrangeira - e da Antiguidade, como também literatura trivial, obras das ciências humanas, da filosofia, política, artigos e periódicos de música e outros. Os Escritos demonstram isso com toda clareza. Neles aparecem citados não apenas autores canônicos da literatura alemã e estrangeira (em especial, Goethe e Shakespeare), mas também autores não canônicos da literatura e da crítica literária - por exemplo, Johann Anton Leisewitz, Wilhelm Heinse, Eugène Scribe e Jules Gabriel Janin -, bem como da música - por exemplo, Christian August Pohlenz, Charles-Auguste Bériot, Daniel Gottlob Türk, Karl Mayer, Pleyel, Vanahl e outros.

Não seria possível citar e comentar todas as referências à literatura contidas nesse primeiro livro dos Escritos. Afinal, a experiência da leitura ele a transformou em música, em reflexões, em vivência; em fonte inesgotável, portanto, para suas composições e escritos. Paulatinamente, Schumann transportou para o interior desse mundo governado pela criação poética seu próprio universo de experiências; a ele o compositor subordinou aos poucos todas as suas ações e projetos, de sorte que - para usar uma terminologia mais atual - a realidade do discurso, separada, como sabemos, por uma tênue linha da realidade dita objetiva, aos poucos foi com ela se confundindo.

Diante, portanto, da impossibilidade de identificar e comentar tudo o que, nos Escritos de Schumann, aponta para esse substrato literário, ${ }^{27}$ digo que, aquilo que timidamente estou chamando de "erudição" do compositor, quer dizer, seu vastíssimo cabedal de leituras, encontra seu correlato na pressuposição, também na falta de melhor palavra, pois - em vários momentos - a mim me parece que Schumann não tem mesmo é paciência com a desinformação dos possíveis leitores e nem tem tempo a perder, em face de tudo o que ainda tem a fazer. ${ }^{28}$

Penso que o círculo de leitores da NZfM não era muito numeroso. Estou certo, também, que Schumann reconhece em seus destinatários ao menos três "partidos", como ele mesmo se refere com frequência ao público em seus Escritos: os

\footnotetext{
${ }^{27}$ Para o Livro I, elaborei uma lista não exaustiva de 53 referências, citações e alusões explícitas à literatura.

${ }^{28}$ Essa "pressa" em dizer muita coisa sem se preocupar em explicar o que diz, também está presente na constituição do texto schumanniano: por vezes faltam nexos sintáticos, verbos auxiliares, conectores, índices de retomada, entre outros, que exigem do leitor o esforço de preencher espaços vazios e reconstruir, assim, a cadeia coesiva.
} 
adeptos dos velhos (e já passados) tempos - isto é, dos mestres e das formas do barroco e do classicismo -, os apreciadores da música de salão e do virtuosismo "vazio" e os (poucos) simpatizantes das novas tendências. Parece-me, então, que o compositor não previu que, com o transcorrer do tempo, esse estado de coisas pudesse ser mudado e que os novos receptores não estariam em condições de preencher os espaços vazios deixados por ele em suas resenhas.

Isso que hoje nos parece óbvio, aparentemente passou despercebido ao compositor no momento de rever seus trabalhos e de transformar suas resenhas em livro, cerca de duas décadas depois de tê-las escrito. Que as opiniões mudem com o tempo - inclusive a dele mesmo -, isso fica claro quando vemos, nas notas de Kreisig, aquilo que foi reformulado ou suprimido no texto final. Também aqui, não seria possível comentar cada uma dessas alterações. Contudo, destaco como característica geral das transformações operadas por Schumann no texto final certa tendência à generalização, ao apagamento do aspecto técnico, por assim dizer, de suas resenhas, em função de considerações de caráter mais amplo. A questão de saber se, ao rever suas resenhas, Schumann teria pretendido efetivamente parecer mais genérico, fica, por ora, sem uma resposta definitiva. Isso porque pode ser, também, que ao rever seus textos ele não tivesse mais parâmetros concretos para aferir a parte técnica: em vários momentos dos Escritos, Schumann reclama dos editores que lhe encomendavam críticas, mas que não lhe enviavam as partituras para análise. Como resultado disso, muitas vezes ele tinha de escrever sobre a obra a partir de uma só audição e sem o apoio da partitura. Seja como for, o apagamento de uma ancoragem mais precisa e, consequentemente, a ampliação da impressão que a obra lhe causou à época parece ser uma tendência que já se esboça neste primeiro livro, conforme deixam patente alguns exemplos arrolados a seguir.

$\mathrm{Na}$ resenha para um trabalho de Loewe (A primavera, poema musical em forma de sonata [em sol] 0.47 ), a Nota 122 (p. 382) traz o seguinte trecho suprimido da versão final:

[suprimido:] "O ritmo do adorável tema talvez se tornasse mais marcado se o baixo começasse na segunda colcheia e as últimas colcheias de cada compasso estivessem ligadas ao compasso seguinte. Pela facilidade com que L[oewe]. lida com as formas e sabe invertê-las, falta-nos, ao final da pág. 10, a retomada do tema, pelo qual se espera depois do dó sustenido que precede e do acorde de ré maior, da dominante ré, ao invés de se chegar a sol passando-se por um repentino dó. O que incomoda está em sol \# e é fácil de ser removido".

Também na nota 124 (p. 382), sobre a Sonata op. 39 de Lachner, lemos:

[suprimido:] "No que respeita especificamente à sonata, presumimos que ela tenha sido, na verdade, uma sinfonia escrita para orquestra e posteriormente arranjada para piano. Confirmada essa hipótese, nossa crítica sobre ela continuaria preservada em seus pontos principais; contudo, preferiríamos que tal observação viesse acoplada ao título, pois Lachner, já de antemão, poderia rechaçar a objeção de que a sonata, enquanto peça para piano, não estaria suficientemente adequada ao instrumento para fazê-lo responder com toda a sua riqueza de sons". 
$\mathrm{Na}$ abertura para $\mathrm{O}$ conto da bela Melusina, de Mendelssohn, Schumann suprime o seguinte trecho (Nota 191, p. 391):

[suprimido]: "Se estes dois últimos [aspectos mencionados], assim como o tipo de instrumentação (mais especificamente no que respeita aos meios expressivos, quando instrumentos isolados vêm e vão alternadamente), nos fazem lembrar algo já ouvido anteriormente, somente uma mente desprovida de compreensão poderia ver unilateralidade nisso"

\section{Também nas resenhas sobre os Trios (1836), encontramos supressões importantes:}

[suprimido:] "O último movimento, no andamento de um rondó, produz o mesmo efeito prosaico do primeiro e se coaduna perfeitamente com ele. Incomoda-me apenas, à página 31, o brando mi maior depois do rígido mi menor, o que me parece um erro estético. Algo que causa pena, pois com pouco esforço se poderia ir da pág. 30 à pág. 32." (Nota 210, p. 393, sobre um trio de Rosenhain)

[suprimido:] "Descendo um pouco mais a pormenores, devo dizer que supus no primeiro movimento do oitavo trio (à página 7) um retorno um pouco menos trivial ao início. Certamente Reissiger compõe em períodos de bela simetria [na maioria das vezes, de quatro em quatro compassos]; com isso, porém, frequentemente ele cai numa prolixidade em que, sem abrir mão da simetria, poderia ser mais conciso. De outra parte, considero primoroso o Scherzo com seu trio eloquente e, da mesma forma, Andantino e o rápido Finale. A mim me parece que o nono Trio deixa um pouco a desejar em relação ao anterior no que respeita à força inventiva e à atitude. Só o Scherzo arroja-se a alçar voos mais altos". (Nota 220a, p. 394, sobre um Trio de Reissiger)

Além das supressões, que acabam deixando incompletas algumas resenhas, Schumann ainda adota, em várias passagens, uma forma generalizante de redigir sua crítica. Embora este aspecto já tenha sido contemplado em parte, quando me referi anteriormente à marca da pressuposição no texto schumanniano e à escrita de seus heterônimos (principalmente de Eusebius), apresento a seguir alguns outros exemplos (um fragmento de resenha e duas resenhas na íntegra) que, somados às supressões que marcaram a revisão do compositor para seus escritos, deixam vagas suas considerações:

"O segundo concerto de Herz parte de dó menor e é recomendado àqueles que gostam do primeiro". Se, por acaso, certa sinfonia em dó menor for apresentada na mesma noite, pede-se que a mesma seja alocada depois do concerto. (parágrafo de fechamento da crítica ao Segundo concerto de Herz, op. 74, p. 153-154)

"Também Napoleão perdeu suas últimas batalhas; mas Arcole e Wagram as ofuscam. Ries escreveu um concerto em dó sustenido menor e pode dormir sossegado sobre seus louros. Mas a que se deve, então, o fato de ainda nos sentirmos tão bem e tão felizes quando ele se revela em obras anteriores - quer dizer, obras anteriores de sua maturidade -, mesmo a despeito de certo esmorecimento da fantasia e da natureza da arte? É a comemoração da maestria, o descanso depois da luta e da vitória, quando não há mais batalhas a enfrentar e nem pelas quais lutar. Nesse sentido, esse nono concerto alinha-se aos seus antecessores. Neles não encontramos, sob nenhum aspecto, qualquer sinal de progresso, nem do compositor e muito menos do virtuose. Os mesmos motivos de antes, sua mesma expressão, tudo bem definido e claro como se não 
pudesse ser diferente; nenhuma nota a menos; a mesma e perfeita fusão dos elementos no conjunto, harmonia, ideia básica, música. - Sobre obras desse tipo é tão difícil e há tão pouco a dizer quanto sobre o azul do céu, que me lança um olhar neste momento através da janela; por isso desejamos que os leitores, que leem esta página neste momento, sejam agraciados por esse mesmo olhar, a fim de que encontrem, tão rapidamente quanto eu, os pontos de comparação entre o concerto de um velho mestre e aquelas faixas de azul que pairam tranquilas lá no alto". ( $9^{\circ}$ concerto de Ries, op. 177 , p. 156-157)

"Quatro quintos dos concertos mais recentes, sobre os quais ainda teceremos comentários aos nossos leitores, estão compostos em tonalidade menor, de sorte que há razões concretas para se temer que a terça maior desapareça completamente do sistema tonal. Assim, quando abri a partitura do concerto em lá maior de Döhler e me deparei com a tonalidade, que mais do que qualquer coisa transborda juventude e força, e pude prever já no título ramos de louro, tive esperança de finalmente ter encontrado uma pessoa agradável, que me pudesse contar muitas coisas da bela Itália, onde ele passou um longo período, e a quem, em agradecimento, eu pudesse transformar os ramos de louro em coroa. No início, tudo parecia aceitável, regular, mas já pela metade, enquanto eu executava uma página ao piano, comecei a lançar à página ao lado olhares esperançosos, pois o compositor me desagradava cada vez mais; por fim, vi-me forçado a lhe dar a prova sincera de que ele ainda não tinha a menor ideia da dignidade da arte para a qual a natureza lhe havia dotado de algumas habilidades, ainda que não em profusão, razão pela qual ele as teria de administrar melhor. Pois se alguém escreve um rondó divertido, deve fazê-lo bem. Mas se alguém se candidata à mão de uma princesa, dele se pressupõe que tenha berço e alma nobres; ou, sem querer parecer supérfluo com tantas imagens, se alguém trabalha com uma forma tão grandiosa da arte, da qual os melhores do país se aproximam com humildade e timidez, ele tem de saber disso. E é exatamente isso o que nos irrita neste caso. Ainda se se tratasse dos compositores mais talentosos dos dias de hoje, Herz e Czerny, que se esforçassem em nos oferecer algo de maior valor em suas obras de grande fôlego! Mas quando um compositor mais jovem e de talento incomparavelmente inferior nos quer impor algo que nem seus padroeiros o fazem, então ele merece ser distinguido, como é o que acontece aqui. Para o bem do compositor, tomara que seu bom espírito permita que estas páginas lhe caiam às mãos antes que ele arrume suas malas pela segunda vez para viajar à Itália e que leve em consideração nosso pedido: que evite um raio de vinte milhas em torno do país que quase sempre nos devolve enfraquecidos e inaptos para o trabalho nossos músicos jovens e vigorosos. A Itália tem os seus cantos mágicos, mas também tem seus próprios compositores para eles; de modo que não há necessidade alguma que engrossemos ainda mais suas fileiras na condição de suíços grosseiros para, no melhor dos casos, atacar nosso próprio país - isso sem pensar no desprezo com que esses desertores são medidos pelos seus novos amigos. Se quiserdes, porém, tirar algum proveito de lá, fazei-o de forma inteligente o suficiente para não terdes de lamentar dez perdas para cada benefício; assim, não sacrificai a força à brandura, a beleza ao adorno. Numa palavra: a polpa à casca! E mesmo tu, divertida cidade imperial, que costuma ter alguns bons artistas entre os teus filhos, não te canses de lembrar a teus jovens artistas, que em teus muros viveu um dos maiores homens de todos os tempos, para que tu, na tua gentil benevolência não os incentives a tomar um caminho que desemboca num banco de areia movediça, no qual eles, leves como nuvens e sob os teus milhares de 'bravos!' se afundem cada vez mais!" (Theodor Döhler, Primeiro Concerto com acompanhamento de Orquestra. Obra 7, p. 149-150).

Às supressões e formulações genéricas soma-se, então, o fato de o lapso de tempo entre a publicação das resenhas na NZfM e o momento em que Schumann as reviu ter levado o compositor a rever alguns de seus primeiros julgamentos. Ao longo dos Escritos, essas reavaliações qualitativas são sutis, muitas vezes sendo expressas através da substituição de um adjetivo ou de um substantivo: 
E façamos nós o mesmo, colocando para esses nossos $\mid$ bons $\left.\right|^{29}$ concertos para piano o título desses dois num mesmo patamar de beleza. (W. Taubert, Concerto com acompanhamento de Orquestra. O. 18, p. 157-160)

Também encontramos uma reconsideração de suas primeiras avaliações sobre a sinfonia de Berlioz (p. 69-90) nas Notas 105 e 106 (p. 378):

Vamos nos abster, aqui, de desenvolver mais essas reflexões, mas gostaríamos, ao final deste parágrafo, de lembrarmos as palavras proféticas, ditas há muitos anos por Ernst Wagner num momento de cândida inspiração poética: "aquele a quem é dado dissimular totalmente e tornar imperceptível a tirania do compasso na música, ao menos conseguirá tornar essa arte aparentemente livre; quem for capaz de lhe dar uma consciência, conferirá a ela o poder de representar uma bela ideia; e a partir desse momento, a música será a primeira de todas as belas artes ${ }^{\varnothing,},{ }^{30}$ (p. 74)

Em todas as passagens em que aparentemente não há uma forma definida, é preciso |reconhecer| $\left.\right|^{31}$ sempre a relação com a ideia, a coerência do conjunto e aqui se poderia pensar numa frase - embora não de toda acertada - que se costuma dizer sobre Jean Paul, a quem alguém chamou de um lógico bruto e de um grande filósofo. (p. 74)

Outra revisão de julgamento também pode ser vista na Nota 110 (p. 380), ainda sobre a Sinfonia de Berlioz:

$\mathrm{Na}$ terceira parte ele desenvolve |de forma particularmente bela $\left.\right|^{32} \mathrm{o}$ tema principal (7) em contraponto; também é digno de nota o modo como ele cuidadosamente transporta o tema para mi bemol maior (8) e para sol menor (9).

Sobre a transcrição para piano da Sinfonia de Berlioz por Franz Liszt, Schumann (re)escreve (Nota 113, p. 381):

A transcrição para piano de Franz Liszt mereceria uma análise extensa e minuciosa; deixemo-la, bem como algumas considerações sobre o tratamento sinfônico do pianoforte, para uma ocasião futura. Liszt dedicou-se ao trabalho de transcrição com tanto afinco e lentusiasmol, ${ }^{33}$ que o resultado não pode ser visto senão como uma obra original, um resumée de seus estudos profundos, uma escola prática do piano para execução à vista de uma partitura.

Na resenha ao Duo a quatro mãos para pianoforte, de W. Taubert, O. 11 (p. $94-$ 96), lemos:

Mas se quiserdes saber o que é possível fazer de um pensamento simples ${ }^{\varnothing 34}$ com perseverança, predileção e, sobretudo, genialidade, voltai os olhos para Beethoven e vede como ele

29 [N.K.] (Escritos, 160, ao meio) Originariamente: "melhores".

${ }^{30}$ [N.K.] (Escritos, 74, ao meio) Suprimido: "Este momento não começaria com a Sinfonia de Berlioz?"

${ }^{31}$ [N.K.] (Escritos, 74, abaixo) Originariamente: "admirar".

32 [N.K.] (Escritos, 79, acima) Originariamente: "como um Mestre".

33 [N.K.] (Escritos, 81, ao meio) Originariamente: "entusiasmo e genialidade".

${ }^{34}$ [N.K.] (Escritos, 96, ao meio) Suprimido: "e, porque não dizê-lo, fraco em si". 
eleva às alturas esse pensamento ${ }^{, 35}$ enobrece-o, e como a palavra, no início comum, acaba por se transformar, em sua boca, num adágio sublime, de validade universal. - Há pouco desejei à obra ampla divulgação. E é o que realmente desejo. Sobretudo é preciso entregar às mãos dessa época jovem, que começa a lançar suas raízes, algo que a guarde da influência maléfica que sobre ela exercem algumas lobras virtuosísticas e de baixo valor|. ${ }^{36}$

São apenas alguns exemplos, mas que - no jogo especular da tradução - revelam, também no domínio da crítica, o compromisso selado por Schumann com seu tempo: a revisão sem fim de parâmetros, a aceitação do inacabado, o esforço da progressão rumo ao aprimoramento.

\section{Para concluir: "A melhor forma de se falar sobre música é calando-se"}

A afirmação é de Schumann e lança uma dúvida sobre a validade mesma da crítica musical, sobre sua eficácia e pertinência. Assim posto, isso parece constituir um contrasenso em vista do fato de o compositor ter-se dedicado, durante anos, à chefia de redação de sua revista e depois, já no fim de sua vida, escolher justamente suas resenhas para rever, transformar em livro e legá-lo à posteridade. Tal contrasenso, porém, não se sustenta, principalmente quando levamos em conta o já mencionado compromisso de Schumann com a arte e os artistas de seu tempo.

De um lado, a arte. Schumann está preocupado em definir o espaço e os contornos de uma crítica que tenha os pés em seu tempo, mas cujos olhos estejam voltados para o futuro; uma crítica, enfim, que avalie a produção musical do início do século XIX tendo por base e parâmetro uma contemporaneidade situada entre o conforto e a inquietação: diacronicamente, entre a produção dos clássicos e a herança do barroco, de um lado, e um porvir ainda sem contornos definidos, de outro; sincronicamente, entre o fascínio do virtuosismo e da música de entretenimento e o anseio por devolver a criação à poesia:

É pouco provável que Berlioz tenha tido mais repulsa ao dissecar a cabeça de um belo assassino ${ }^{37}$ do que eu tive para fazê-lo com seu primeiro movimento. E será que consegui oferecer algo de útil ao meu leitor com essa dissecação? Minhas intenções com ela foram três: em primeiro lugar, mostrar àqueles que desconhecem completamente esta sinfonia, quão pouco thes pode ser explicado, na música, através de uma crítica analítica; em segundo, indicar alguns pontos essenciais àqueles que passaram os olhos superficialmente por ela e que, sem saberem o que fazer $e$ nem como se orientarem nela, talvez a tenham colocado de lado; em terceiro, finalmente, provar àqueles que a conhecem, sem quererem lhe reconhecer os méritos, que - a despeito de uma aparente ausência de forma - habita este corpo uma ordem absolutamente simétrica, medida em proporções maiores, para não mencionar sua coerência interna. (Sinfonia de H. Berlioz, p.72, grifos meus)

35 [N.K.] (Escritos, 96, ao meio) Suprimido: "(frequentemente negativo, ao remeter para a beleza que se encontra próxima dele)".

${ }^{36}$ [N.K.] (Escritos, 96, abaixo) Originariamente: "obras de interesses menores ou geradas pela paixão imoral".

37 [N.S.] Ele estudou medicina em sua juventude. 
De outro lado, os artistas. Com eles Schumann se confraterniza e, mesmo não se acanhando em reconhecer a rudeza das palavras frente à linguagem da música, das artes "a mais delicada", encontra na identificação e na solidariedade com seus correligionários outra base de sustentação da crítica:

É claro que se deve prevenir contra o que seja feio e obsceno; nada há, porém, que torne as coisas mais medíocres do que falar mediocremente sobre elas ${ }^{38}$. Nenhum artista, porém, precisa de um espelho florescente de sua arte mais do que o músico, cuja vida frequentemente termina em contornos tão sombrios; nenhuma arte se deveria tratar com mais delicadeza do que a mais delicada, ao invés de prepará-la para o consumo com as mãos rudes de um açougueiro. (Grande Duo para dois pianofortes, de I. Moscheles. Obra 92, p. 181-182; grifos meus)

É nesse sentido que, a meu ver, se podem interpretar as afirmações em caráter de manifesto do compositor na resenha aos dois concertos de Frédéric Chopin (p. 164-167), que escolhi para concluir essa breve exposição sobre sua escrita crítica:

Ao vos deparardes com adversários, jovens artistas, regozijai-vos com este sinal da força de vosso talento e considerai-a tanto maior, quanto mais resistentes forem aqueles. Ainda assim, continua digno de nota o fato de que, naqueles anos muito áridos antes de 1830, em que as pessoas deveriam ter dado graças aos céus por um ramo de palha, a própria crítica - que, naturalmente, sempre vem a reboque quando não emana de cabeças produtivas - deu os ombros por tanto tempo ao reconhecimento de Chopin, havendo mesmo um ${ }^{39}$ que se atreveu a dizer que as composições de Chopin seriam boas para serem rasgadas. Chega dessas coisas! Mesmo o Duque de Módena ainda não reconheceu Louis Philippe e se o trono de barricadas não repousa sobre pés de ouro, isso certamente não é por causa do Duque. Talvez eu devesse mencionar de passagem uma revista de pantufas ${ }^{40}$ que, pelo que ouvimos dizer (isso porque não a lemos e nos sentimos lisonjeados, aqui, de possuir alguma pouca semelhança com Beethoven - vede os Estudos de Beethoven, editados por Seyfried -) pelo que ouvimos dizer, portanto, nos sorri por debaixo da máscara com os olhos mais doces e, também, afiados como punhais, só porque certa feita eu disse sorrindo a um de seus colaboradores, um colaborador que havia escrito alguma coisa sobre as Variações de Don Juan, de Chopin, que ele - o colaborador -, à semelhança de um verso mal escrito, possuía alguns pés a mais e que se deveriam cortá-los no tempo oportuno! - Mas porque me lembrar dessas coisas hoje, quando acabo de ouvir o Concerto em Fá menor de Chopin? Longe de mim tais ideias! Leite contra veneno; leite azul, frio! Pois o que representam as resenhas de um ano inteiro de uma revista musical em face de um concerto de Chopin? O que representa o desvario de um magistrado face ao poético? O que representam dez coroas de redação em face de um Adagio no segundo concerto? E para dizer a verdade, meus caros companheiros da Confraria de Davi, eu não vos julgarei dignos de uma palavra sequer sobre obras que não fôreis capazes de compor vós mesmos, excetuadas algumas, é claro, como

38 [N.K.] (Escritos, 182, acima) Suprimido: "De nossa parte - enquanto não encontramos correligionários que, do mesmo modo como preferimos escrever sobre alguns descendentes, se alonguem sobre outros - preferimos, ao menos por enquanto, tomar a nós a crítica de uma unilateralidade momentânea do que concordar num tom superficial e geral que, em seus elogios, muito mais mal faz do que a pseudoparceria e a paixão por escândalos".

39 [N.K.] (Escritos, 164, ao meio) Rellstab, referindo-se às Mazurkas, Op. 7 (“Íris", 1833, p. 112).

${ }^{40}$ [N.K.] (Escritos, 164, abaixo) A "Allgem[eine] Musikal[ische] Zeitung", de Fink. 
justamente este segundo concerto, do qual nem todos nós juntos seríamos capazes de nos aproximar, ou que conseguiríamos, no máximo, beijar a barra da saia. Fim às revistas musicais! Sim, o triunfo e o objetivo supremo de uma boa revista (e em cuja direção muitas já trabalham) deveria ser o de se elevarem até tão alto, que ninguém mais as lesse por não ter o que fazer e que o mundo inteiro, tomado pela produtividade, não quisesse mais nem ouvir falar de escrever sobre isso; - da mesma forma, a meta suprema do crítico honesto (e também aqui alguns se esforçam nesse sentido) seria o de se tornar totalmente supérfluo; - a melhor forma de se falar sobre música é calando-se. 